\title{
Det perikapitalistiska landskapet
}

\section{Jenny Jarlsdotter Wikström}

The Mushroom at the End of the World: On the Possibility of Life in Capitalist Ruins

Anna Lowenhaupt Tsing

Princeton University Press, 2015

I boken The Mushroom at the End of the World granskar antropologen Anna Lowenhaupt Tsing kapitalismens gränsland. Som sin särskilda kompanjon i detta utforskande utser hon svampen goliatmusseronen, även kallad matsutake. Tsings anspråk är, för att uttrycka det milt, mycket stora: hon vill bygga en verktygsback för en feministisk anti-antropocentrisk kritik av kapitalismen. De ambitiösa anspråken vägs upp genom att Tsing genomgående betonar vikten av det partikulära. Hur kapitalismen fungerar som en praxis där säljare och kund förs samman, hur oväntade handelns vägar kan te sig i ett landskap där svampar, tallar, flyktingar och samhällets utstötta möts. Hon väljer en negligerad handelskedja - handeln med goliatmusseronen - som sitt exempel eftersom hon ser att det där, i det prekära, sårbara och oväntade, öppnar sig en möjlighet för en analys av kapitalismen som ett öppet system som det är möjligt att förändra. Mushroom är följaktligen ett slags manifest för en annan typ av kapitalismkritik än vad vi är vana vid.

Efter uppsvinget för kritiska djurstudier under 2000-talets 
första årtionde har växter hamnat i fokus. Bland annat Jeffrey T. Nealon för fram i Plant Theory. Biopower \& Vegetable Life (Stanford University Press, 2016) att växtligt liv svårligen ryms inom den kritiska teorins ramverk. Svampar, å sin sida, har fått en liknande uppmärksamhet den senaste tiden, inte minst genom Tsing och hennes kollegers forskning om goliatmusseronen, som växer i Japan, Kina, USA, Kanada och vissa delar av Skandinavien.

Varför just goliatmusseronen, kan en fråga sig. En förklaring är att den är otroligt efterfrågad men inte kan odlas i laboratorium. Svampen är en av världens dyraste och måste plockas $\mathrm{i}$ skogen. Det betyder att goliatmusseronen ingår i en komplex kedja av svampplockare, köpare och internationella förmedlingsagenturer, och, förstås, även som en del av själva skogen. Tsing ser här det hon kallar ett "perikapitalistiskt" landskap: i utkanten av handelskedjan finns plockare, som för både nöjes och pengars skull letar efter spåren av den värdefulla svampen i skogar världen över.

"Follow fungi to that underground city, and you will find the strange and varied pleasures of interspecies life" (138), skriver Tsing. Den underjordiska stad som hon i sällskap med plockare finner under den täta mattan av tallbarr kopplar samman kroppar och livsvärldar märkta av den globala kapitalismen. Goliatmusseronerna lever intimt sammanlänkade med sina värdträd - i detta fall olika typer av tall - för att få tillgång till näring $\mathrm{i}$ marken genom svampens rottrådar; svampar jobbar rhizomatiskt, de äter sten och jord och döda växtdelar och formar aktivt sin levnadsmiljö. De är del av ett intrikat, levande nätverk som är sårbart för förändringar. Tsings poäng är att alla arter uppkommer och lever på detta sårbara, känsliga rhizomatiska sätt, men i goliatmusseronens fall framgår det med extra stor tydlighet.

De nätverk som Tsing spårar är varken harmoniska, idylliska eller ofarliga, vilket också är en av bokens allra viktigaste poänger. Goliatmusseronen trivs i förstörda landskap, där lantbruk och skogsbruk har orsakat kalhyggen och ödelagt biotoper. Svampen trivs till och med där det inte finns någon växtjord att 
tala om. Därför är svamp en bra ledstjärna till teoretiseringen av återväxt, motsträvighet, och naturens agens och påhittighet. De utmanar antropocentriska föreställningar om individualitet, agens och intentionalitet genom hur de skapar livsvärldar tillsammans med andra arter också i landskap där skogsmaskiner tuggat sönder träd och jord. Svampar är, enligt Tsing, utmärkta guider till att förstå kapitalismen just av den anledningen - de lever kvar i ruinerna, när kapitalismens skogstuggande maskineri har dragit vidare.

Kapitalismen är ett system, framhåller Tsing, men inte ett slutet sådant. Dess logik äter upp skogar, men upphör efter att skogsmaskinerna avverkat den värdefulla skogen och lämnat kvar ett öde land utan värde. I det öde, prekära och vid första anblicken förstörda landskapet frodas sedan goliatmusseronen. Handeln med goliatmusseronen är beroende av skogslandskapet och av människor som letar och plockar svamp, men även av andra informella handelslogiker som inte följer kapitalismens rätlinjiga lagar om produktion, utbud och efterfrågan. På så sätt hittar Tsing en öppning till en kritik av kapitalismen i hur goliatmusseronen inte kan anpassas till kapitalismens logik utan förblir sin egen. Svampen finns - eller så finns den inte. Och någon måste också hitta svamparna för att de ska kunna bli en vara på den globala marknaden.

Svampen ingår därför inte bara i nätverk tillsammans med växter och träd. De som plockar goliatmusseronen och som Tsing följt under år av fältarbete är också på flera sätt präglade av kapitalismens framfart. I Oregon är svampplockarna ofta av sydostasiatiskt ursprung. I boken skildrar Tsing hur hon intervjuar och plockar svamp tillsammans med medlemmar ur mien-, lao- och hmongminoriteter, människor som tvingats fly från krig eller som valt att emigrera. Med sig har de haft kunskapen om var och hur svampen lever. En annan del av svampplockarna i Oregon är amerikanska krigsveteraner som velat lämna en i deras ögon svekfull civilisation. Plockarna som Tsing intervjuar är överlevare, de har överlevt krig, de har också ofta själva begått våldsbrott, och förenas av en odefinierbar längtan efter "frihet". Plockarna väcker själva frågor om vad det vill säga att överleva 
i en skrämmande, föränderlig och förstörd värld. Här finns en koppling till den tes som Timothy Morton driver i boken Hyperobjects (2013): vi kan inte "rädda världen", den värld vi vill rädda har redan gått under för länge sedan. Frågan är vad som sker efter världens undergång, vem eller vilka är det som finns kvar när dammet lägger sig. Vad är förstörelse, och för vem?

Det anmärkningsvärda med Tsings bok är hur hon ser ickemänskliga livsvärldar som helt grundläggande för kapitalismen, och hur hon formulerar möjligheter till förändring av kapitalismens struktur. Hon letar aktivt efter platser och landskap där den kritiska teorin brister, där den marxistiska feminismens analyser av arbete, varulogik och produktionsförhållanden helt enkelt inte håller måttet eftersom den inte tar icke-mänsklig agens i beaktande. Mushroom kan också läsas som en fortsättning på den kritik av antropocenens narrativ som feminister, svarta feminister, queer- och transforskare formulerat. De komplexa och heterogena nätverken som goliatmusseronen skapar och är en del av löper djupa och vildvuxna genom kroppar; träd, skogar, svampplockare, försäljare, lokala handelsplatser, fram till någons tallrik och in i kroppar som hakar i andra kroppar. I likhet med J.K. Gibson-Graham i A Postcapitalist Politics (University of Minnesota Press, 2006) vill Tsing utveckla nya kritiska redskap, och startar med att medge att kapitalismen inte är en monolit, utan ett system med gränser. Vad kan vi göra av denna vetskap om att kapitalismen är beroende av ickekapitalistiska praktiker, frågar hon sig. "Economic diversity enables capitalism but also undermines its hegemony" (132), förklarar hon.

Fokuset på det materiella är ett effektivt sätt att kringgå alienationsproblematiken, det vill säga separationen mellan den sammansatta produktionen av en vara och varan själv. Svampen skapas inte ur intet, den är en relation mellan mikrober, alger, jordmån, träd, en hel livsvärld som sedan vecklas in i människorna som plockar den, vilka i sin tur snärjs in i kapitalismens mångfacetterade nätverk. Kedjan har varken en tydlig början eller ett tydligt slut och blir således ett exempel som stöder Tsings hypotes om att kapitalismen så att säga läcker. Genom att metodiskt arbeta med en relationell etik i analysen av goli- 
atmusseronens varufiering kan Tsing visa på hur motsägelsefull kapitalismen är, hur den bygger på komplexa relationer som är svåra att greppa med den befintliga marxistiska teorins redskap. Boken fungerar således som en typ av handbok, eller ett slags manual, och bör således slutgiltigt värderas enligt hur den sätts i omlopp och används av andra forskare, inom andra discipliner under åren som kommer.

Tsings slutsatser har också problematiska sidor. Å ena sidan strävar hon efter att återge och analysera kapitalismen som ett öppet, läckande och föränderligt system. Å andra sidan platsar goliatmusseronen så väl in i analysen att läsaren blir misstänksam: är allt frid och fröjd nu när vi förstått att kapitalismen har inbyggda brister? Hur ska vi motarbeta miljöförstörelse, ekonomisk ojämlikhet och rovdrift, om dessa bara är tecken på kapitalismens förestående undergång? Ska vi bara vänta och se? Visst är det viktigt att teoretisera förstörelse och naturens egen förmåga att förgöra och skapa nytt, men det som går förlorat när kapitalismen upphör att vara ett system är ju just systemkritiken, protesten, motståndet. Kan inte också diskursen om den monolitiska kapitalismen ibland förstås som "strategisk essentialism" som gör den hanterbar, möjlig att motarbeta? Kan inte hederlig, gammal systemkritik användas till någonting alls? Goliatmusseronens förmåga att frodas på ställen där marknaden dragit vidare kan ju lika väl förstås som helt i enlighet med kapitalismens marknadslogik: där ingen marknad finns, skapas en ny.

Jag fick smaka goliatmusseron tack vare en kollega vid Umeå Universitet, som känner någon, som i sin tur känner någon som hittat svampen i Vindeln, en liten stad nordväst om Umeå. Den smakade umami, en sträv men varm smak. Genom den kedjan av händelser ingår också jag nu i nätverket som Tsing spårar, det löper genom svampen på tallriken in i min kropp, och vidare. Just den här goliatmusseronen var en gåva till min kollega, som i sin tur delade gåvan med mig. Det här kan tänkas vara oviktiga 
detaljer, men så är det inte. Och här håller jag med Tsing, varan, i detta fallet svampen jag äter, är inte bara en funktion, den är materia, den har en egen tyngd och den lämnar spår som inte platsar inom den traditionella marxistiska varulogiken. Materialiteten finns oberoende av kapitalismen, svampen är sin egen.

De märkliga, invecklade turer som varor och varelser gör inom kapitalismen visar på brister och håligheter i systemet. Kanske visar de även på möjligheter till förändring, om vi ska tro Tsing. På många sätt är nyfikenhet nyckeln till den förändringen, för hon fram: "Not that it will save us - but it might open our imaginations." (19). Frågan är vart en mer öppen föreställningsförmåga leder. 